\title{
Dorota Wyszkowska
}

Uniwersytet w Białymstoku

e-mail: d.wyszkowska@uwb.edu.pl

\section{SAMODZIELNOŚĆ FINANSOWA GMIN W OPINII SKARBNIKÓW GMIN W POLSCE}

\section{FINANCIAL AUTONOMY OF COMMUNES IN THE OPINION OF THE TREASURERS OF COMMUNES IN POLAND}

DOI: $10.15611 / \mathrm{pn} .2018 .518 .12$

JEL Classification: H71, H72

Streszczenie: Celem pracy jest przedstawienie subiektywnej oceny poziomu samodzielności finansowej gmin w Polsce dokonanej przez skarbników tych jednostek. Badaniem objęto 160 celowo dobranych gmin z 2478 gmin w Polsce. Do skarbników tych gmin skierowano kwestionariusz badawczy. Badanie przeprowadzono w okresie grudzień 2016-luty 2017. W opinii skarbników gmin poziom samodzielności wydatkowej gmin jest wyższy niż samodzielności dochodowej, co pozostaje w sprzeczności z poglądami prezentowanymi w literaturze przedmiotu, mówiącymi, że to samodzielność dochodowa wiedzie prym i determinuje samodzielność wydatkową. Jednocześnie skarbnicy wskazali na najbardziej pożądane źródła dochodów, które nie są związane ze zwiększeniem poziomu samodzielności dochodowej tych jednostek. Realizacja założonego celu pracy wymagała zastosowania studiów literaturowych, przeanalizowania danych budżetowych gmin oraz przeprowadzenia badania ankietowego wśród skarbników gmin w Polsce.

Słowa kluczowe: gmina, samodzielność finansowa, samodzielność dochodowa, samodzielność wydatkowa.

Summary: The aim of this paper is to present a subjective assessment of the level of financial autonomy of communes in Poland made by the treasurers of these units. The study covered 160 deliberately selected communes from 2478 communes in Poland. A research questionnaire was sent to the treasurers of these communes. The study was conducted in December 2016-February 2017. In the opinion of the treasurers of communes, the level of expenditure autonomy of communes is higher than revenue autonomy, which is in contradiction with the literature that revenue autonomy leads the way and determines expenditure autonomy. At the same time, the treasurers pointed to the most desirable sources of revenue, which are not related to the increase in the income-related autonomy of these units. The implementation of the assumed objective required the use of literature studies, analyzing the budget data of communes and conducting a survey among the treasurers of municipalities in Poland.

Keywords: commune, financial autonomy, revenue autonomy, expenditure autonomy. 


\section{Wstęp}

Samodzielność finansowa gmin w Polsce jest tematem często podejmowanym przez różnych autorów, zwłaszcza w kontekście oceny jej poziomu i determinant ją kształtujących ${ }^{1}$. Jest ona oceniana zwykle przez pryzmat analizy wskaźnikowej, odnoszącej się zwłaszcza do udziału różnych kategorii dochodów własnych w dochodach ogółem lub też różnych kategorii wydatków w wydatkach ogółem (por. [Dylewski, Filipiak, Gorzałczyńska-Koczkodaj 2010, s. 93-96; Filipiak, Dylewski, Gorzałczyńska-Koczkodaj 2011, s. 100; Markowska-Bzducha, 2005, s. 167; Łukomska-Szarek 2012, s. 275; Zawora 2014, s. 556]).

Dokonywane oceny pomijają jednak subiektywne odczucia poziomu samodzielności finansowej w aspekcie dochodowym i wydatkowym osób, które na co dzień zarządzają środkami budżetowymi gmin. Poznanie ich opinii wydawało się dość cenne, zwłaszcza w kontekście dodatkowych możliwości kształtowania potencjału inwestycyjnego gmin dzięki zwiększeniu poziomu ich samodzielności finansowej. Czy poziom samodzielności finansowej gmin wywiera wpływ na ich potencjał inwestycyjny, a w konsekwencji na aktywność inwestycyjną JST? W dotychczas prowadzonych badaniach obie te kategorie nie były analizowane łącznie.

Należy zauważyć, że przyznanie gminom szerokiego zakresu i poziomu samodzielności finansowej, po stronie zarówno dochodowej, jak i wydatkowej powinno sprzyjać poprawie racjonalności, skuteczności i efektywności gospodarowania ograniczonymi środkami budżetowymi, a w konsekwencji pozwalać na wygospodarowanie wolnych środków, które podstawowe JST mogłyby przeznaczać na podejmowanie działalności inwestycyjnej [Jastrzębska 2012]. Potwierdzenia powyższej tezy można upatrywać w doświadczeniach skandynawskich. To właśnie w Norwegii, Szwecji i Finlandii odpowiedniki polskich gmin charakteryzują się najwyższym poziomem samodzielności finansowej, dysponując jednocześnie najwyższym poziomem środków przeznaczanych na inwestycje samorządowe.

Także w literaturze przedmiotu podkreśla się, że im większy jest poziom samodzielności gmin w pozyskiwaniu dochodów, tym większa jest presja na efektywne nimi gospodarowanie, co w powiązaniu z rosnącą świadomością mieszkańców i ich możliwością dostrzeżenia nieefektywności działania władz może prowadzić do istotnych zmian. Przyznanie na stałe gminom określonych źródeł dochodów wraz z instrumentami władztwa podatkowego wobec tych źródeł powinno pozwolić im na lepsze wieloletnie planowanie rozwoju wspólnoty samorządowej z określeniem strategii inwestycyjnej, a następnie jej konsekwentne realizowanie. Efektywność systemu podatków lokalnych jako efektu zwiększenia samodzielności dochodowej JST należy odnieść przede wszystkim do: zapewnienia wystarczających dochodów

1 O samodzielności finansowej w Polsce piszą m.in.: K. Piotrowska-Marczak, K. Sawicka, K. Brzozowska i M. Kogut-Jaworska, M. Jastrzębska, B. Filipiak, M. Dylewski, E. Kornberger-Sokołowska, S. Owsiak, M. Kosek-Wojnar, P. Swianiewicz, L. Patrzałek, M. Poniatowicz, W. Miemiec, K. Surówka, E. Feret, J. Heller, S. Kańdula, E. Markowska-Bzducha, J. Zawora, A. Babczuk. 
na sfinansowanie zadań samorządowych oraz „wzmacniania demokracji lokalnej, również w kontekście sprzyjania identyfikacji określonych preferencji mieszkańców" [Guziajewska 2016, s. 277].

Celem pracy jest przedstawienie subiektywnej oceny poziomu samodzielności finansowej gmin w Polsce dokonanej przez skarbników tych jednostek. Badaniem objęto 160 celowo dobranych gmin z 2478 gmin w Polsce 2 . Do skarbników tych gmin skierowano kwestionariusz badawczy w wersji elektronicznej ${ }^{3}$. Wypełnione ankiety otrzymano ze 114 gmin. Badanie przeprowadzono w okresie grudzień 2016 - luty 2017 i stanowiło ono element szerszego badania poświęconego ustaleniu istnienia zależności pomiędzy poziomem samodzielności finansowej (w aspekcie dochodowym, wydatkowym i przychodowym) a poziomem potencjału inwestycyjnego gmin w Polsce. Wyniki badania zostały przedstawione na tle analizy poziomu samodzielności finansowej przeprowadzonej z wykorzystaniem danych budżetowych.

\section{Poziom samodzielności finansowej gmin w ocenie skarbników jednostek}

Dotychczas nie były prowadzone w Polsce badania jakościowe w zakresie podjętym w opracowaniu. Wśród gmin były realizowane analizy dotyczące pożądanego kierunku zmian w systemie ich finansowania czy też zakresu konkurencji podatkowej gmin $^{4}$. Poznanie opinii osób zajmujących się finansami lokalnymi na temat poziomu samodzielności finansowej gmin w połączeniu z analizą wskaźnikową z wykorzystaniem danych budżetowych pozwala na wypracowanie rekomendacji w zakresie niezbędnych zmian, prowadzących do zwiększenia poziomu analizowanej samodzielności gmin.

Jak już zauważono, najczęściej oceny poziomu samodzielności dochodowej i wydatkowej gmin dokonuje się na podstawie analizy wskaźnikowej. W tabeli 1 zaprezentowano najczęściej stosowany w literaturze przedmiotu wskaźnik do oceny samodzielności dochodowej - wskaźnik autonomii lokalnej, natomiast w tabeli 2 wskaźnik do oceny samodzielności wydatkowej obrazujący udział wydatków ma-

2 Doboru dokonano, kierując się średnią wysokością wskaźnika dochodów podatkowych z trzech ostatnich lat, stosowanego przez Ministerstwo Finansów do naliczania subwencji ogólnej. Z każdego z województw wybrano 5 gmin o poziomie minimalnym i maksymalnym tego wskaźnika, aby możliwe było pozyskanie opinii skarbników gmin, które mogą być traktowane jako „bogate” i „,biedne”.

3 Zwrotu wypełnionych ankiet skarbnicy dokonywali w wersji elektronicznej lub papierowej.

4 Warto zauważyć, iż w badaniach przeprowadzonych przez A. Babczuka w 2008 r. wśród JST w zakresie pożądanych kierunków zmian w systemie finansowania samorządu terytorialnego dominująca grupa jednostek wskazywała na wszelkiego rodzaju dochody transferowe, a jedynie niewielka na te dochody podatkowe, na które jednostki te mają lub mogłyby mieć wpływ. Miasta na prawach powiatu (64,52\%) wskazały jako najbardziej pożądane źródło zwiększenie udziałów w podatkach dochodowych stanowiących dochody budżetu państwa, a 12,9\% na źródła wyrównawcze potencjał dochodowy. W przypadku gmin najbardziej pożądanymi źródłami dochodów są te same, co wśród miast na prawach powiatu. Szerzej: [Babczuk 2009, s. 173-179; Swianiewicz, Łukomska 2016]. 
jątkowych w wydatkach ogółem (jako tych, wobec których gminy mają największą swobodę dysponowania).

Tabela 1. Udział dochodów własnych (bez udziału w PIT i CIT) w dochodach ogółem (w \%)

\begin{tabular}{|l|c|c|c|c|c|c|c|c|c|c|c|}
\hline & 2006 & 2007 & 2008 & 2009 & 2010 & 2011 & 2012 & 2013 & 2014 & 2015 & 2016 \\
\hline Gminy miejskie & 39,4 & 39,1 & 38,7 & 37,7 & 37,1 & 35,6 & 36,1 & 36,9 & 37,3 & 36,1 & 32,3 \\
\hline $\begin{array}{l}\text { Gminy miejsko- } \\
\text {-wiejskie }\end{array}$ & 33,1 & 32,9 & 32,3 & 31,3 & 31,3 & 31,0 & 31,5 & 32,7 & 33,2 & 32,5 & 28,3 \\
\hline Gminy wiejskie & 27,6 & 27,6 & 25,9 & 25,0 & 25,0 & 25,2 & 26,1 & 27,3 & 28,3 & 28,2 & 23,9 \\
\hline $\begin{array}{l}\text { Miasta na pra- } \\
\text { wach powiatu }\end{array}$ & 35,7 & 34,5 & 37,4 & 36,2 & 36,6 & 35,9 & 35,2 & 36,8 & 37,1 & 36,5 & 34,3 \\
\hline
\end{tabular}

Źródło: opracowanie własne na podstawie danych GUS, http://stat.gov.pl/obszary-tematyczne/rachunki-narodowe/statystyka-sektora-instytucji-rzadowych-i-samorzadowych/gospodarka-finansowa-jednostek-samorzadu-terytorialnego-2014,5,11.html (data dostępu: 18.11.2017), oraz MF http://www.finanse.mf.gov.pl/budzet-panstwa/finanse-samorzadow/opracowania (data dostępu: 02.03.2018).

Uwzględniając poziom wskaźników zaprezentowanych w tab. 1, można stwierdzić, że zwłaszcza w przypadku gmin wiejskich trudno jest mówić o samodzielności dochodowej w sytuacji, gdy jednostka w niespełna 1/3 swoich dochodów pozyskuje je ze źródeł, które pozostają w zasięgu ich jakiegokolwiek oddziaływania (nawet wobec części tych źródeł nie dysponując instrumentami władztwa podatkowego). Co może niepokoić, analizowany udział spada. Jeszcze mniej korzystnie kształtują się wskaźniki udziału wydatków majątkowych w wydatkach ogółem, co może być interpretowane jako niski poziom samodzielności wydatkowej analizowanych jednostek.

Tabela 2. Wydatki majątkowe w relacji do wydatków ogółem (w \%)

\begin{tabular}{|l|c|c|c|c|c|c|c|c|c|c|c|}
\hline & 2006 & 2007 & 2008 & 2009 & 2010 & 2011 & 2012 & 2013 & 2014 & 2015 & 2016 \\
\hline Gminy miejskie & 20,4 & 18,6 & 20,6 & 22,4 & 23,0 & 20,7 & 16,3 & 13,9 & 15,5 & 14,5 & 10,3 \\
\hline $\begin{array}{l}\text { Gminy miejsko- } \\
\text {-wiejskie }\end{array}$ & 19,2 & 17,8 & 19,6 & 22,0 & 23,8 & 22,0 & 17,6 & 15,7 & 17,3 & 16,1 & 10,6 \\
\hline Gminy wiejskie & 20,6 & 18,9 & 19,9 & 23,0 & 26,3 & 23,8 & 18,4 & 17,7 & 19,4 & 17,9 & 11,3 \\
\hline $\begin{array}{l}\text { Miasta na pra- } \\
\text { wach powiatu }\end{array}$ & 19,9 & 22,5 & 22,7 & 23,0 & 22,3 & 21,2 & 19,9 & 19,1 & 20,9 & 18,5 & 10,7 \\
\hline
\end{tabular}

Źródło: opracowanie własne na podstawie danych MF http://www.finanse.mf.gov.pl/budzet-panstwa/ finanse-samorzadow/opracowania (data dostępu: 02.03.2018).

Przedstawione kształtowanie się dwóch najbardziej typowych wskaźników do oceny poziomu samodzielności gmin stanowi tło dla prezentacji wyników przeprowadzonych badań prezentujących subiektywną ocenę skarbników gmin w zakresie będącym przedmiotem opracowania. Badania miały dostarczyć informacji, których 
pozyskanie nie jest możliwe z innych źródeł ${ }^{5}$. Uzyskane opinie umożliwiły ocenę stopnia samodzielności gmin w Polsce oraz pożądanych kierunków zmian w zakresie kategorii dochodów i wydatków polskich gmin mogących służyć zwiększeniu ich samodzielności dochodowej i wydatkowej. Uwzględniając istnienie, choć istotnie ograniczonego, władztwa podatkowego gmin, podjęto się również określenia głównych przesłanek stosowanych, w granicach ustawowych, preferencji podatkowych.

Na podstawie uzyskanych wyników podjęto się odpowiedzi na pytanie, czy JST w Polsce są w rzeczywistości zainteresowane zwiększeniem stopnia samodzielności finansowej czy też oczekują zwiększenia dochodów ze źródeł pozostających w gestii władzy centralnej.

Skarbnicy ankietowanych gmin wśród najbardziej pożądanych źródeł zwiększenia swoich dochodów najczęściej wymieniali subwencję ogólną oraz udziały w podatkach stanowiących dochody budżetu państwa (PIT i CIT), a więc źródła, z których środków budżetowych mogą swobodnie korzystać, ale jednocześnie nie ponoszą odpowiedzialności za kształtowanie ich elementów konstrukcyjnych. Pozostałe źródła ustawowe oraz podatki i opłaty, wobec których gminy dysponują ograniczonym władztwem podatkowym, nie były wskazywane tak często jako najbardziej pożądane. O ile można zrozumieć brak zainteresowania pierwszym z wymienionych źródeł ze względu na ich niską wydajność fiskalną, o tyle małe zainteresowanie drugim źródłem wskazuje na to, że gminy nie są zainteresowane rzeczywistym zwiększaniem swojej samodzielności dochodowej i przypisaniem im większych dochodów ze źródeł, na które mogłyby mieć rzeczywisty wpływ. Rozkład odpowiedzi odnoszących się do wskazania najbardziej pożądanych źródeł dochodów gmin został przedstawiony na rys. 1 .

Podejście skarbników gmin do źródeł finansowania bez względu na to, czy są to jednostki biedne czy bogate, nie różni się istotnie. W przypadku jednych i drugich są to te same źródła, jednak gminy bogate najczęściej jako te najbardziej pożądane wskazywały udziały w podatkach stanowiących dochody budżetu państwa (66\%), a biedne - subwencję ogólną (66\%). Zastanawiający jest jednocześnie fakt, że gminy biedne równie często jak gminy bogate wskazywały jako najbardziej pożądane źródło podatki i opłaty, wobec których gminy dysponują ograniczonym władztwem podatkowym, choć ich dochody z tego tytułu są znacznie niższe.

5 Ankieta została skierowana do skarbników gmin. Poprawnie wypełnione ankiety zostały przesłane ze 114 gmin, w tym 53\% - z gmin o najniższym poziomie dochodu podatkowego na mieszkańca, oraz $47 \%$ - z gmin o najwyższym poziomie dochodu podatkowego na mieszkańca. W dalszej części opracowania będą stosowane określenia „biedne gminy” i ,bogate gminy” z uwzględnianiem poziomu wskaźnika dochodów podatkowych. 


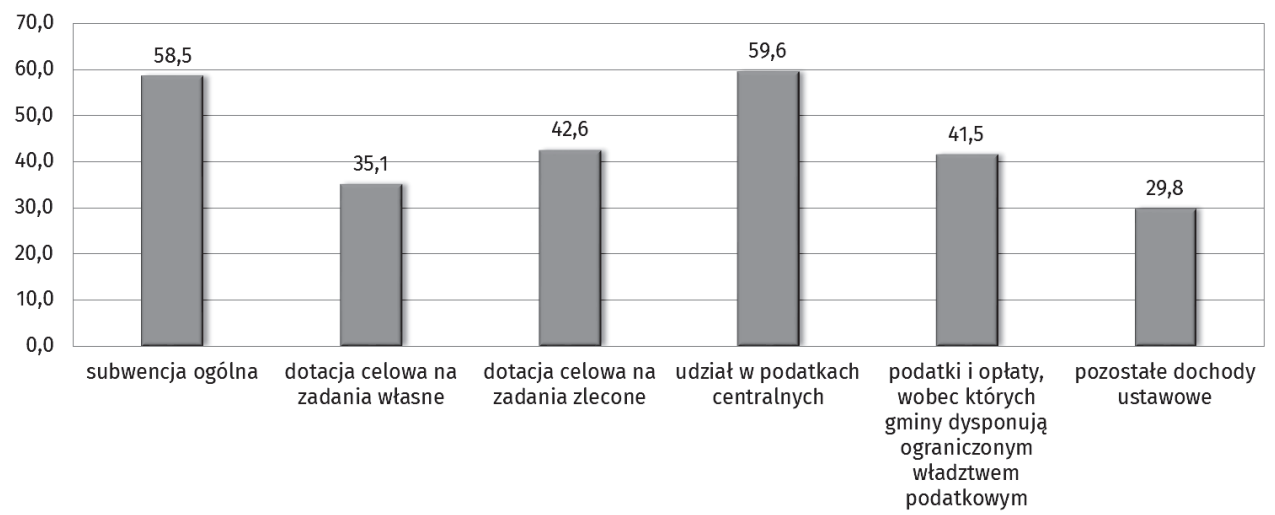

Oznacza udział procentowy wskazań dokonanych przez skarbników gmin odpowiedzi 1 i 2 w pięciostopniowej skali (gdzie 1 oznaczało najbardziej pożądane źródło, a 5 - najmniej) w ogólniej liczbie gmin uczestniczących w badaniu.

Rys. 1. Najbardziej pożądane źródła zwiększenia dochodów gmin (w \%)

Źródło: opracowanie własne na podstawie wyników badań ankietowych.

Skarbnicy gmin, dokonując oceny stopnia samodzielności finansowej gmin w Polsce po stronie dochodowej i wydatkowej, oceniali ją na średnim poziomie, zaznaczając wartość $3 \mathrm{w}$ pięciostopniowej skali (dochodowa - 53\%, wydatkowa $51 \%)$. Zdecydowanie inaczej kształtowały się wskazania gmin, jeśli chodzi o niższy i wyższy poziom samodzielności dochodowej i wydatkowej. Biorąc pod uwagę pierwszy aspekt samodzielności, poniżej wartości średniej wskazało $31 \%$ ankietowanych, a powyżej - 15\%, natomiast w odniesieniu do aspektu wydatkowego poniżej poziomu średniego wskazało prawie $14 \%$, a powyżej $35 \%$. Uzyskane dane świadczą o tym, że skarbnicy gmin oceniają na wyższym poziomie samodzielność wydatkową niż dochodową podstawowych JST w Polsce. Ocena stopnia samodzielności finansowej w obu analizowanych aspektach różni się pomiędzy bogatymi i biednymi gminami. Skarbnicy gmin bogatych wskazywali na średni $(56 \%)$ lub wyższy (21\%) poziom samodzielności dochodowej zdecydowanie częściej niż biednych, w których wielkości te osiągnęły odpowiednio poziom 50\% i 10\%. Jeszcze większą dysproporcję można zaobserwować w ocenie stopnia samodzielności wydatkowej. W tym przypadku skarbnicy gmin bogatych oceniali ją na średnim poziomie w $52 \%$ lub wyższym w $39 \%$, podczas gdy biednych - na poziomie średnim w $50 \%$, a powyżej w $32 \%$.

Kolejnym zagadnieniem, które zostało poddane badaniu, było określenie uprawnień, jakie powinny zostać przyznane gminom odnoszącym się do ich dochodów i przychodów. Najwięcej zwolenników miało przyznanie gminom prawa do samodzielnego ustalania stawek opłat i podatków, natomiast najmniej - prawo do bezli- 
mitowego korzystania ze zwrotnych źródeł finansowania oraz ustalania dopłat do podatków państwowych (rys. 2).

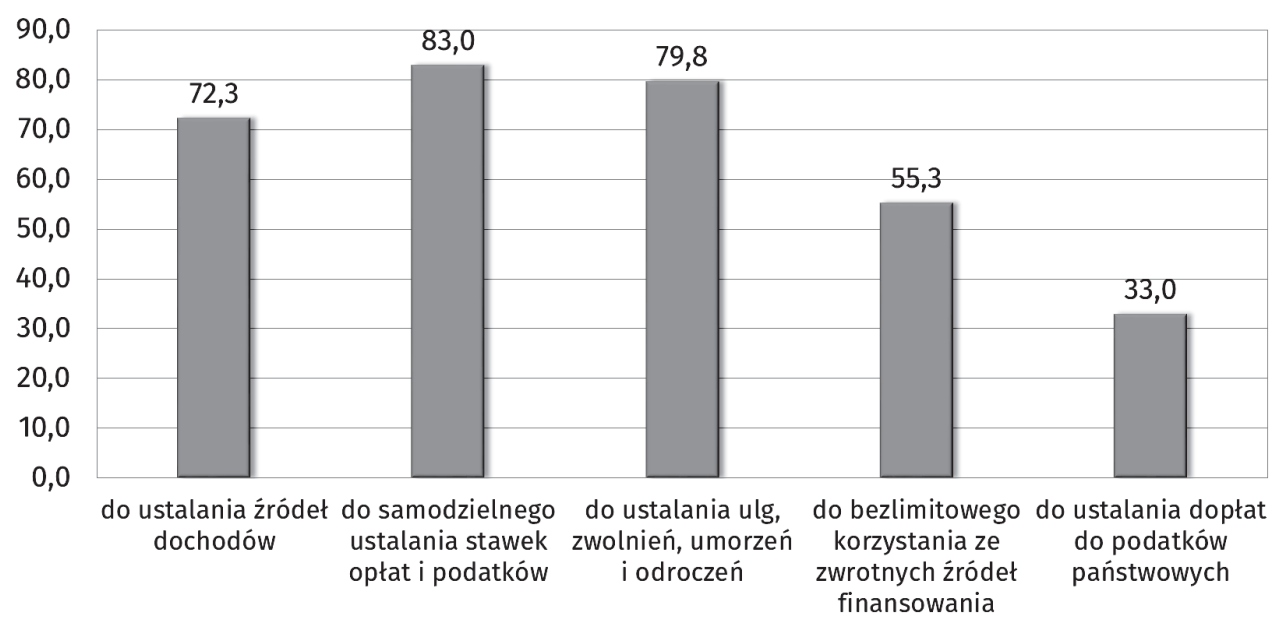

Odpowiedzi „tak” na pytanie: jakie uprawnienia (prawa) odnoszące się do dochodów i przychodów powinna mieć gmina w Polsce?

Rys. 2. Odsetek wskazań poparcia skarbników gmin dla uprawnień gmin w zakresie dochodów i przychodów (w \%)

Źródło: opracowanie własne na podstawie wyników badań ankietowych.

Analizując odpowiedzi dotyczące gmin biednych i bogatych, nie zauważa się istotnych różnic, z wyjątkiem zainteresowania ustalaniem dopłat do podatków centralnych. Blisko połowa skarbników gmin bogatych (48,8\%) opowiedziała się za przyznaniem gminom tego uprawnienia, podczas gdy biednych tylko niespełna $21 \%$. Można przypuszczać, że wynika to $\mathrm{z}$ faktu, iż w przypadku gmin biedniejszych, zwłaszcza wiejskich, ten rodzaj dochodów miałby niewielkie znaczenie fiskalne. Niskie zainteresowanie tym źródłem dochodów może także wynikać ze zbyt małej wiedzy skarbników na jego temat, jak również z niechęci do przekazywania samorządowi kolejnego źródła dochodów, o którego wykorzystaniu musiałaby decydować sama jednostka (wprowadzenie dopłat byłoby niepopularne wśród mieszkańców).

Skarbnikom gmin w ankiecie zostało również zadane pytanie odnoszące się do uprawnień, jakie należałoby przyznać gminom w zakresie wydatkowania środków budżetowych. Zarówno w tym przypadku, jak i w odniesieniu do dochodów starano się poznać opinię w zakresie zagadnień mających wpływ na samodzielność finansową. Wśród uprawnień odnoszących się do wydatków skarbnicy najczęściej wskazywali na samodzielne ustalanie zakresu realizacji zadań oraz realizację zadań ustawowych we współpracy z innymi JST, natomiast najrzadziej na odmowę 
realizacji zadań zleconych (rys. 3). Nie zaobserwowano w zasadzie żadnych różnic w tym zakresie w przypadku odpowiedzi skarbników gmin bogatych i biednych.

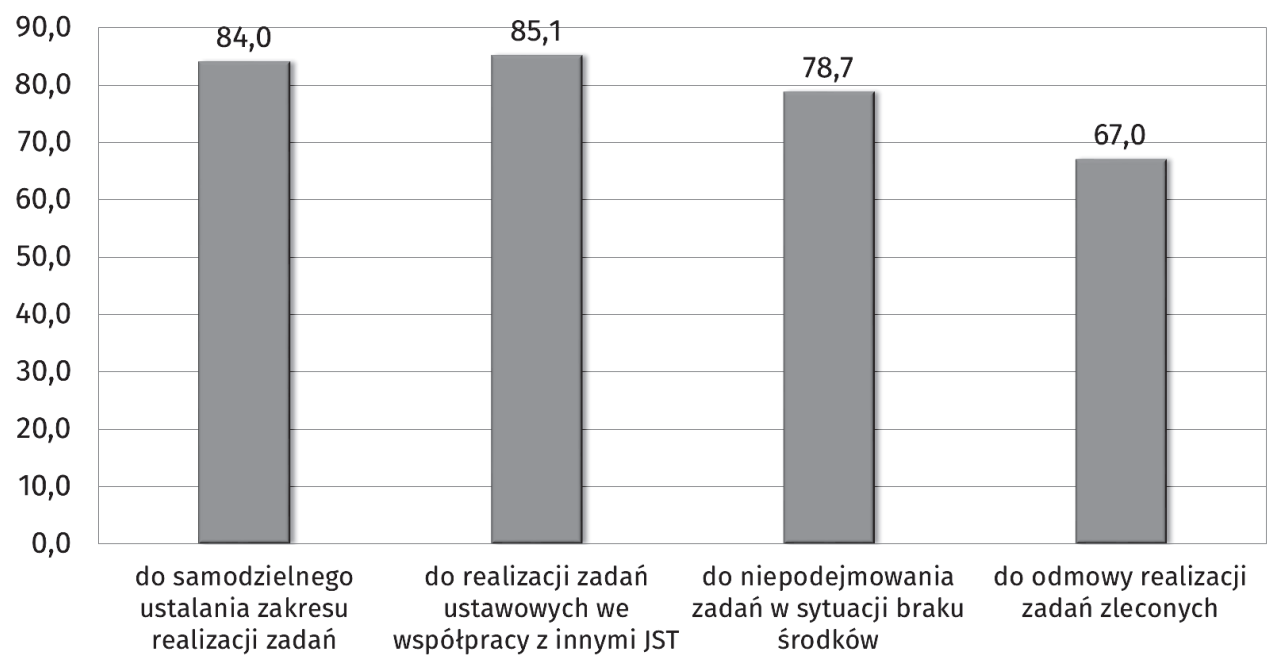

Odpowiedzi „tak” na pytanie: jakie uprawnienia (prawa) odnoszące się do wydatków powinna mieć gmina w Polsce?

Rys. 3. Odsetek wskazań poparcia skarbników gmin dla uprawnień gmin w zakresie wydatków (w \%) Źródło: opracowanie własne na podstawie wyników badań ankietowych.

Ze względu na to, że gminy w Polsce dysponują istotnie ograniczonym władztwem podatkowym w odniesieniu do nieznacznej liczby źródeł podatkowych, intersujące było poznanie przesłanek, jakimi kierują się podstawowe JST w udzielaniu określonych preferencji podatkowych. Skarbnicy gmin najczęściej jako najważniejszą przesłankę wskazywali zachętę dla lokalizacji przedsiębiorców, natomiast najrzadziej poprawę efektywności działania podmiotów/rolników (rys. 4).

Bogate gminy wśród przesłanek mających bardzo istotny wpływ na przyznawanie preferencji wskazywały znacznie częściej dwie pierwsze przesłanki oraz ostatnią przedstawione na rys. 4 (np. w przypadku 1 było to $58,5 \%$ wobec $35,4 \%$ ), natomiast gminy biedne nieco częściej wskazywały przesłankę 3 (50\% wobec 48,8\%). Jedna z gmin wskazała również inną przyczynę, a mianowicie - ochronę środowiska. Można przypuszczać, że gminy biedne, w których poziom zamożności mieszkańców także nie jest wysoki, stosują preferencje podatkowe w celu poprawy ich sytuacji, natomiast celem gmin bogatych jest przyciąganie podmiotów gospodarczych i mieszkańców. Należy jednak pamiętać, że to gminy wiejskie, najczęściej reprezentujące gminy biedne, w znaczenie większym zakresie wykorzystują instrumenty władztwa podatkowego niż najbogatsze jednostki (miasta na prawach powiatu). 


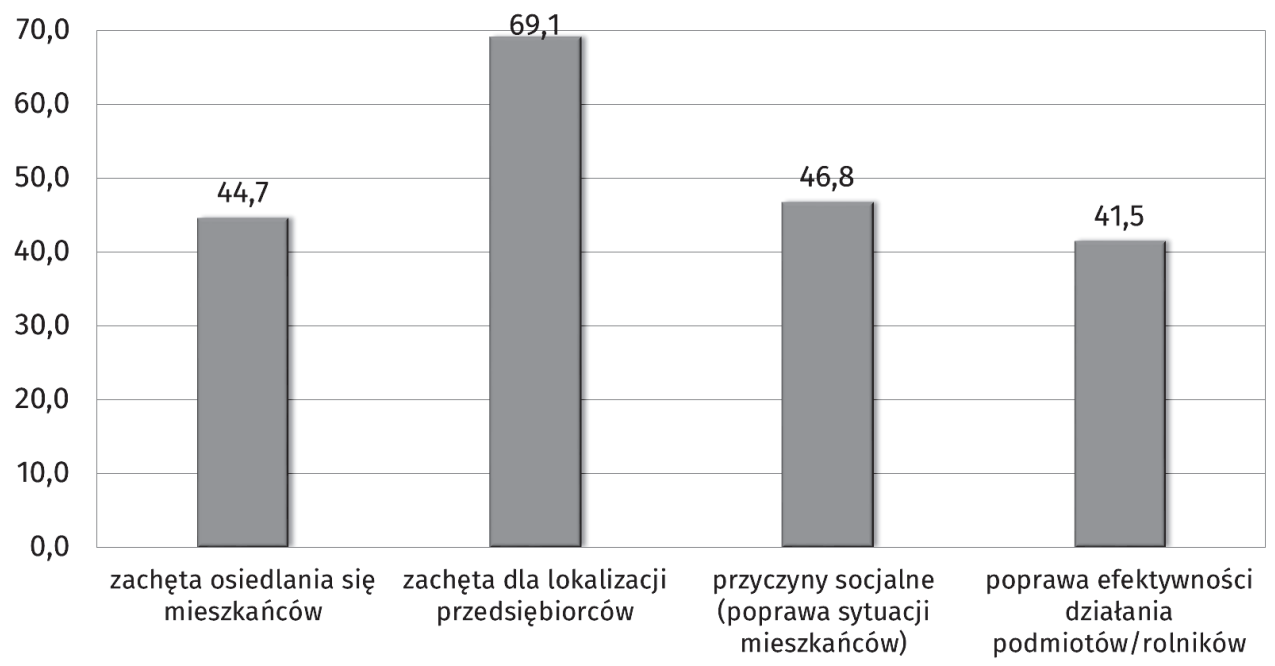

Oznacza udział procentowy dokonanych przez skarbników gmin wskazań odpowiedzi 4 i 5 w pięciostopniowej skali (gdzie 1 oznaczało mały wpływ, a 5 - bardzo duży) w ogólniej liczbie gmin uczestniczących w badaniu.

Rys. 4. Przesłanki stosowania preferencji podatkowych przez gminy (w \%)

Źródło: opracowanie własne na podstawie wyników badań ankietowych.

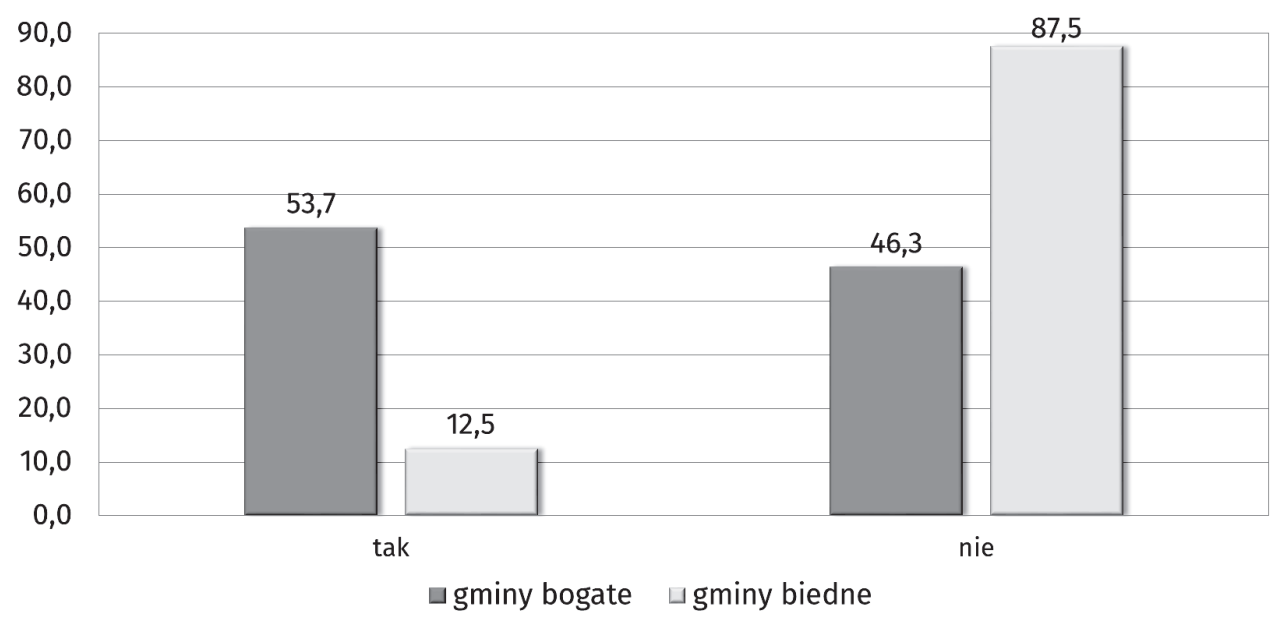

Rys. 5. Czy ograniczenie stosowania subwencji równoważącej prowadziłoby do wzrostu samodzielności dochodowej gmin (w \% odpowiedzi)?

Źródło: opracowanie własne na podstawie wyników badań ankietowych. 
Uzyskane odpowiedzi pozwalają także stwierdzić, że ograniczenie stosowania subwencji równoważącej nie prowadziłoby do wzrostu samodzielności dochodowej gmin $(68,5 \%)$. Jednak w tym przypadku rozkład odpowiedzi jest zdecydowanie odmienny, jeśli wziąć pod uwagę gminy biedne i bogate. Rozkład ten zaprezentowano na rys. 5.

Aby odpowiedzieć na pytanie, czy część równoważąca subwencji ogólnej w ogóle ma wpływ na analizowany aspekt samodzielności finansowej, skarbnikom zostało zadane dodatkowe pytanie - czy ograniczenie stosowania subwencji równoważącej prowadziłoby do spadku samodzielności dochodowej gmin. Uwzględniając odpowiedzi na poprzednie pytanie, należało spodziewać się wysokiego odsetka gmin wskazujących na odpowiedź „tak”. Skarbnicy gmin odpowiadali jednak głównie „nie” (51,7\%), Co można świadczyć o tym, że poziom tej samodzielności w opinii znacznej części skarbników nie zależy od części równoważącej subwencji ogólnej, która nie odgrywa w dochodach gmin znaczącej roli. Rozkład odpowiedzi w podziale na gminy biedne i bogate zaprezentowano na rys. 6 .

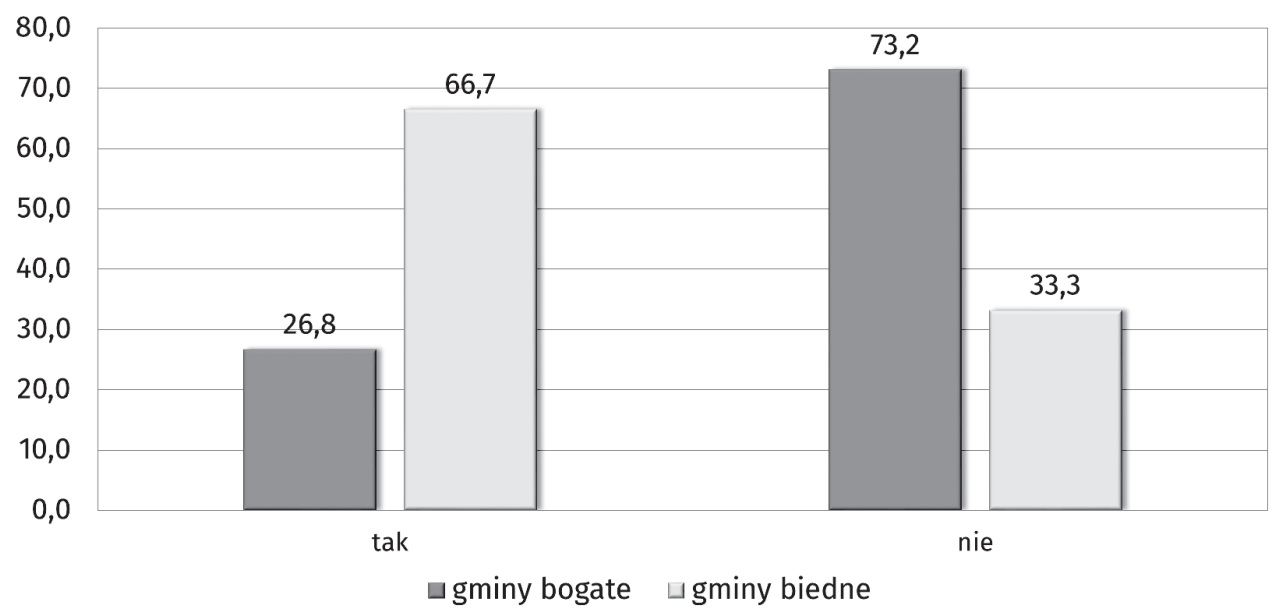

Rys. 6. Czy ograniczenie stosowania subwencji równoważącej prowadziłoby do spadku samodzielności dochodowej gmin (w \% odpowiedzi)?

Źródło: opracowanie własne na podstawie wyników badań ankietowych.

\section{Samodzielność finansowa a potencjał inwestycyjny w opinii skarbników gmin w Polsce}

Z punktu widzenia podjętego tematu ważne było również poznanie opinii skarbników gmin w zakresie czynników, które mogłyby doprowadzić do wzrostu ich potencjału inwestycyjnego. Wśród tych czynników wskazano na zwiększenie samo- 
dzielności dochodowej, ograniczenie zadań obligatoryjnych bieżących, zwiększenie samodzielności wydatkowej, zwiększenie wielkości przyznawanych dotacji celowych inwestycyjnych, zniesienie limitów w zakresie zadłużenia JST, zapewnienie lub zwiększenie udziałów w podatkach stanowiących dochody budżetu państwa ${ }^{6}$. Zdecydowana większość skarbników opowiedziała się za zapewnieniem lub zwiększeniem udziałów w podatkach stanowiących dochody budżetu państwa (83\%) oraz zwiększeniem wielkości przyznawanych dotacji celowych inwestycyjnych (74\%), co ponownie wskazuje na kierunek, w jakim skarbnicy gmin chcieliby, aby podążały zmiany systemu finansowania gmin. Zaprezentowany rozkład odpowiedzi na rys. 7 może wynikać, z jednej strony, z braku chęci przejęcia odpowiedzialności za szeroko rozumianą politykę fiskalną gmin, z drugiej zaś - z dość realistycznego podejścia osób odpowiadających za finanse gmin do obecnie obowiązującego zakresu samodzielności finansowej w aspekcie zarówno dochodowym, jak i wydatkowym oraz braku przekonania o możliwości istotnej poprawy w tym zakresie w najbliższej przyszłości.

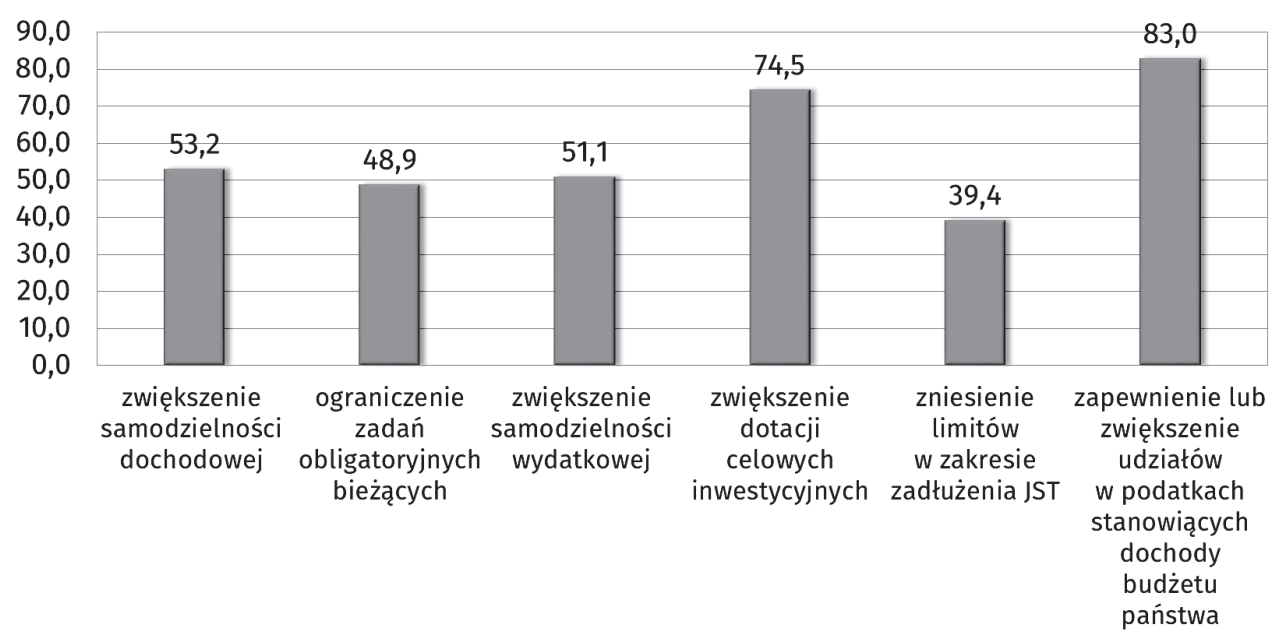

Oznacza udział procentowy wskazań dokonanych przez skarbników gmin odpowiedzi 4 i 5 w pięciostopniowej skali (gdzie 1 oznaczało brak, a 5 duży wpływ) w ogólnej liczbie gmin uczestniczących w badaniu.

Rys. 7. Czynniki zwiększające potencjał inwestycyjny gmin w opinii skarbników gmin w Polsce (w \%) Źródło: opracowanie własne na podstawie wyników badań ankietowych.

Wśród odpowiedzi skarbników gmin bogatych i biednych można zauważyć pewne różnice, a mianowicie skarbnicy gmin bogatych częściej jako elementy w

6 Mówiąc o zapewnieniu udziału, miano na myśli tego typu podatki, w których obecnie gminy nie partycypują, np. podatek od wartości dodanej VAT, który w części krajów UE stanowi dochód sektora samorządowego. 
istotny sposób wpływające na potencjał inwestycyjny gmin wymieniali zwiększenie samodzielności dochodowej (61\% wobec 46\%) oraz, co ciekawe, zwiększenie dotacji celowych inwestycyjnych (77\% wobec 72\%) i zapewnienie lub zwiększenie udziałów w podatkach stanowiących dochody budżetu państwa (86\% wobec 80\%). Taki rozkład odpowiedzi może wynikać z przyczyn opisanych powyżej.

Skarbnicy gmin biorący udział w badaniu w sposób jednoznaczny opowiedzieli się za tym, że wzrost samodzielności finansowej doprowadziłby do wzrostu potencjału inwestycyjnego gmin (85,4\%). Jeszcze bardziej jednoznaczne stwierdzenie można zauważyć wśród skarbników gmin bogatych $(90,2 \%)$. Natomiast biorąc pod uwagę gminy biedne, należy podkreślić, że nieco rzadziej wskazywały one na istnienie takiej zależności $(81,3 \%)$.

\section{Zakończenie}

Wnioski nasuwające się po przeprowadzeniu badań potwierdzają ogólne spostrzeżenia innych autorów prezentowane w opracowywanych w ostatnich latach raportach podsumowujących funkcjonowanie samorządu terytorialnego w Polsce. Podkreśla się w nich, że gminy w Polsce, podobnie jak pozostałe jednostki samorządu terytorialnego, nie są samodzielne w zasadzie w żadnej sferze swojej działalności, w tym w sferze finansów. Przypisano im co prawda udziały w podatkach, ale trudno jest je zaliczyć do własnych źródeł dochodów, biorąc pod uwagę brak możliwości oddziaływania na to źródło dochodów [Samorząd 2013; Bober, Hausner 2013; Misiąg 2016]. Gminy w coraz większym stopniu uzależniane są od rządowych dotacji i subwencji. Autorzy opracowań zauważają także, że od początku funkcjonowania reaktywowanego po roku 1989 samorządu terytorialnego w Polsce nie przypisano mu władztwa podatkowego na odpowiednim poziomie [Bober, Hausner 2013, s. 81].

Brak samodzielności można zaobserwować nie tylko po stronie dochodów, ale także po stronie wydatków. Gminy zobligowane są do przeznaczania środków na realizację określonych zadań, z jednoczesnym szczegółowym uregulowaniem zasad wydatkowania środków [Samorząd 3.0... 2013, s. 4].

Sytuacja jest o tyle niekorzystna, że brakuje obecnie całościowej koncepcji finansowania zarówno gmin, jak i pozostałych JST, a podejmowane rekonstrukcje systemu zasilania budżetów mają charakter doraźny, co jeszcze bardziej go komplikuje. Sprawia też często, że samorząd terytorialny w pewnym zakresie staje się jedynie podmiotem pośredniczącym w wydatkowaniu środków publicznych na ściśle określone cele, w ściśle określonym zakresie i w ściśle określony sposób, bez możliwości prowadzenia własnej polityki rozwojowej, w tym realizacji działalności inwestycyjnej stanowiącej jedną z podstawowych aktywności, dla których został powołany (dla rozwoju wspólnot samorządowych).

Wyniki przeprowadzonego badania stanowią wstęp do dalszych badań, zwłaszcza w zakresie samodzielności wydatkowej podstawowych JST, która pozostaje słabo rozpoznanym obszarem badawczym. Zasadne byłoby zrealizowanie komplek- 
sowego, pogłębionego badania samodzielności finansowej we wszystkich trzech aspektach - dochodowym, wydatkowym i przychodowym wśród wszystkich gmin w Polsce. Analizowanie tej samodzielności jedynie przez pryzmat wskaźników budżetowych nie pozwala na pełną jej ocenę. Zasadne jest określenie przez pryzmat tych badań potrzeb w zakresie zmian systemowych odnoszących się do samodzielności finansowej sprzyjających racjonalizacji zarówno pozyskiwania dochodów budżetowych, jak i ich wydatkowania z punktu widzenia osób zarządzających finansami gmin.

Wyniki badania wskazały, że gminy, mimo częstych deklaracji ich przedstawicieli, nie są w rzeczywistości zainteresowane zwiększeniem poziomu dochodów pozyskiwanych ze źródeł własnych (w tym zwiększeniem zakresu władztwa podatkowego wobec tych źródeł). Środki przekazywane przez państwo nie wymagają bowiem dbałości o bazę podatkową gmin i pozwalają uniknąć odpowiedzialności władzy lokalnej za niepowodzenia związane z wielkością uzyskiwanych przez nią dochodów. Takie zachowanie władz gminnych może wskazywać, że nie są zainteresowane także dbałością o racjonalność i efektywność wydatkowanych środków, którymi dysponują, ani zwiększeniem przejrzystości finansowania gmin i zainteresowania mieszkańców źródłami zasilania finansowego gmin. Najbardziej pożądanymi źródłami dochodów są te, w przypadku których gminy są de facto odbiorcami środków, niezależnie od podejmowanych działań.

\section{Literatura}

Babczuk A., 2009, Samodzielność finansowa jednostek samorządu terytorialnego. Pożadane kierunki zmian w świetle badań ankietowych, Zeszyty Naukowe Uniwersytetu Szczecińskiego, nr 547, Ekonomiczne Problemy Usług nr 37, Finanse 2009 - teoria i praktyka: finanse publiczne, t. 2, s. 173-179.

Bober J., Hausner J. i in., 2013, Narastajace dysfunkcje, zasadnicze dylematy, konieczne działania. Raport o stanie samorzadności terytorialnej w Polsce, Uniwersytet Ekonomiczny w Krakowie, Małopolska Szkoła Administracji Publicznej, Kraków.

Dylewski M., Filipiak B., Gorzałczyńska-Koczkodaj M., 2010, Metody analityczne w działalności jednostek podsektora samorządowego, Difin, Warszawa.

Filipiak B.Z., Dylewski M., Gorzałczyńska-Koczkodaj M., 2011, Analiza finansowa budżetów jednostek samorządu terytorialnego, MUNICIPIUM, Warszawa.

Guziajewska B., 2016, W poszukiwaniu efektywnego systemu podatków samorządowych, Annales Universitatis Mariae Curie-Skłodowska, Lublin - Polonia SECTIO H Vol. L, 1, s. 275-283.

Jastrzębska M., 2012, Finanse jednostek samorządu terytorialnego, Wolters Kluwer, Warszawa.

Łukomska-Szarek J., 2012, Analiza wskaźnikowa w procesie zarządzania finansami samorzadów lokalnych, Studia i Materiały. Miscellanea Oeconomicae, Wydział Zarządzania i Administracji Uniwersytetu Jana Kochanowskiego w Kielcach, nr 2, s. 271-285.

Markowska-Bzducha E., 2005, Samodzielność finansowa polskich gmin, Politechnika Rzeszowska, Rzeszów. 
Misiąg W., 2016, Finanse samorzadowe po 25 latach - stan i rekomendacje, Bank Gospodarstwa Krajowego, Warszawa.

Samorząd 3.0. Raport Forum Od-nowa, 2013, Warszawa.

Swianiewicz P., Łukomska J., 2016, Lokalna konkurencja podatkowa, Studia Regionalne i Lokalne, nr $2(64)$.

Zawora J., 2014, Możliwości finansowania inwestycji gmin wiejskich w Polsce, Roczniki Naukowe SERiA, Tom XVI, Zeszyt 6, Wydawnictwo WIEŚ JUTRA Sp. z o.o., Warszawa-Poznań-Lublin, s. $555-560$. 